\title{
Strange bedfellows: The new neoliberalism of catholic schooling in the United States
}

\author{
Kevin J. Burke
}

Abstract: The article utilizes critical social theory and critical religious theory to examine the emergent and historically aberrant alignment between Catholic schools and neoliberal market-based reforms in the United States. The author traces the historical split between Catholic and public schooling, attending to the role of the litigious in shaping American parochial contexts. In the face of declining enrollments and vocations as well as skyrocketing tuition and a contracting share of the educational 'market,' Catholic leadership has sought public support through market instruments (tax credits and vouchers) in order to preserve dying religious schools. Lost in this paradigm shift is the irony of the move from proud separatism to a governmental reliance that would have seemed abhorrent thirty years ago. Missing, too, in the rhetoric of 'saving Catholic schools' is concern for the harm done to education on a whole when religious schools are presented as competitors with, rather than alternatives to, a free public education. Examined through the lens of the largest provider of Catholic schoolteachers in the United States, the article ultimately concludes that the public good is being sacrificed at the altar of religious pride.

Key words: critical social theory, critical religious education theory, neoliberalism, catholic schooling, vouchers

\section{Emplacing and a brief History}

Elsewhere (Burke \& Segall, 2011) I have been party to an argument that the assumed secular character of American public education is something of a canard that takes an ahistorical view of schooling as curriculum and more importantly as imbued with religious assumptions about student possibility and student bodies borne of a long entwinement of schooling with religion. In this section I intend to do something of the same focusing rather on the founding character of the US Catholic school system for the sake of illustrating what I take to be an underexamined recent (and problematic) 
move by the system as represented increasingly by University actors, toward dependence on governmental support for the sake of survival. This is no libertarian argument lamenting the overreach of incipient bureaucracy. Indeed it will strike readers who follow the political contours of the US as odd that the Catholic Church, for all its protestations of the supposed infringement upon religious liberties by the government regarding the Obama administration's contraception mandate ${ }^{1}$, would seek government injunction and fiscal support in the quest to strengthen and save Catholic schools. In order to make sense of this cognitive dissonance one might merely look to the money, but for a fuller picture of the increasing alignment of Catholic schooling with neoliberal marketized reforms in the United States, one has to first engage the unique and until late, independently proud history of these parochial schools. In the process we will encounter a system of schooling facing extreme contraction caused by a number of factors, primarily due to financial exigency. Indeed data from the National Catholic Education Association (2012) illustrates a steady decline in enrollment through the last ten years that has been marked by a rash of school closings and a dispersion of nearly half a million students ${ }^{2}$. To flesh out the irony of the current climate in which Catholic schools have, as I will illustrate in the third section of this article, tied themselves increasingly with the fortunes of the push for what is colloquially called the Charter and Choice movement, we will need to first outline a rough history of religiosity, law and their twinned roles in (mis) shaping the educational system of the United States.

I will thus seek, in this section, not necessarily to break new ground as regards the historical ties between church and public schooling but rather to set the stage for and trace the wellspring of inherently evangelizing concerns still intertwined with the language and practice of current educational policy, discourse, and pedagogy in the United States. As such, it is vital to note that the history of American schools as proselytizing institutions begins, well, at the beginning.

That Jesus, in the Christian Scriptures is often referred to by the Apos-

1 For a reasonable discussion of the issues at hand we might turn to Cathleen Kaveny on The Daily Show: <http://www.thedailyshow.com/watch/thu-march-1-2012/exclusive---cathleen-kaveny-extended-interview-pt--1>. For the histrionics, one might just track Cardinal James Dolan's open letters in various news outlets and his steady rise to prominence among the Curia in Rome.

2 For the sake of scale, consider the American public school system, according to census data (2010) sat at right around 48 million students in 2008 (the latest available data). Catholic schools in 2010 enrolled roughly 2 million students. This is not an insignificant number, but we might consider the implications of policy moves by Catholic leaders that disproportionately affect the larger group in the name of the smaller group as increasingly troubling and in some sense immoral. 
tles as "rabbi" gave early American common school pedagogues reason enough to weave religion into the moral-curricular fabric of what were essentially frontier seminary schools in colonial America. Indeed Catholic theological history is rife with images of teacher-student relationships. Though the Puritans who spent months a-ship from England would have been suspicious of Papist claims on anything but their specific circle of hell, one probably hears the echoes of St. Ignatius, who wrote that he felt "God led him like a schoolchild" (Kolvenbach, 1986) through his work establishing the Jesuit order, in his Protestant brethren schoolmasters reading from The New England Primer. The most commonly used educational text in the American colonies the Primer (precursor to the McGuffey Readers of 19th century westward expansion fame) at its peak boasted "perhaps 3 million copies [printed]...Its great theme was God and our relationship to Him" (Nord, 1995, p. 65). Simple claim here: prime the children to have a relationship to the Christian God as all knowledge came from Him (this exclusively male, white Deity).

But this is meant, or was begun, as a discussion of religious education vis a vis public education. These schools-excepting, perhaps those efforts of the Jesuits and other evangelizing orders like them-in the Puritanical context of the earliest settlements of a nascent America would not yet have considered the dichotomy between public and private that we see as so stark some four hundred years later. Indeed, in the Colonial period where white, Protestant families were largely charged with the education of their children within the home, a common schools movement on par with anything seen in contemporary England, wouldn't quite get underway in the U.S. until Horace Mann took his case on horseback up and down the Northeast in the mid-1830s.

A shift in the mid-19th century which led to the systematization of the Common schools movement in America was meant to "create a moral, disciplined, and unified population prepared to participate in American politics" (Carper, 1998, p. 16). This population (still) was, of course, white and Protestant and mostly affluent and schooling outside of the home was meant

3 Webb (2000) notes that Christianity left behind the title of rabbi for Jesus, which not only denigrated Christianity's dependence upon Judaism but also devalued pedagogy in general (p. 101). In Christian history James Carroll (2001) discusses the worrisome split created through Christian revisionist historical work which stresses Christ as Christian rather than as a Jewish man who-perhaps unintentionally even-most likely saw himself as a leader of a new kind of Judaism. And so, often enough, we see Jesus addressed as "teacher" instead of Rabbi to accentuate a troubling and all-toooften violent split between a supersessionist Christianity and the "old" religion of the Jews. Carroll calls this history-as-remembered and illustrates it through analysis of the four Gospels for their increasingly political rhetorical construction. 
to prepare Americans for participation in a Christian civilization (p. 16). While, from today's standpoint, we might consider the "common" and religious schools as separate entities, this was in no way the case at the time. The fact is not only that such a separation was inconceivable then but that Protestants, the largest "common" religious affiliation at the time, could not imagine a "common" that was not inherently Protestant in nature. As Carper (1998) notes:

With few exceptions, notably several Lutheran and Reformed bodies, which opted for schools designed to preserve cultural and/or confessional purity, Protestants were generally supportive of common schooling. Indeed, many were in the vanguard of the reform movement. They approved of early public schooling because it reflected Protestant beliefs [and] was viewed as an integral part of a crusade to fashion a Christian, which, to the dismay of Roman Catholics, meant Protestant - America. According to church historian Robert T. Handy (1971), elementary schools hardly had to be under the control of particular denominations because their role was to prepare young Americans for participating in the broadly Christian civilization toward which all evangelicals were working. (p. 11-12)

While the idea that the common school ought to serve as a vehicle of and for Protestantism, was accepted as natural and commonsensical to the Protestant majority in the U.S., it was not seen as such by the waves of immigrants, some of whom, and in growing numbers, were not Protestant. In other words, the commonality of Protestantism as the basis for the common school was soon put into question.

Perhaps one can credit, or blame the Catholics ${ }^{4}$. Well, probably the AntiCatholic Know-Nothing party whose violence against the Catholics in and around New York City and Philadelphia, along with an objection toward a perceived Protestant bias inbred within the curriculum of municipal public schools, led to the establishment under the auspices of Bishop John Hughes of the first Catholic school system in the United States just after the 1840s (Nord, 1995). Coupled with state injunctions that sought to protect

4 My intention is not to be flip here. As a Roman Catholic myself I come from a neighborhood where Protestant leaders burned crosses at news of a priest's having purchased land in the area, fearing that the Irish menace would breed them out of their land. In the end, as I find myself back in Chicago surrounded by St. Barnabas, Christ the King, St. Cajetan, and St. John Fisher parishes, I realize those stern German would-be aristocrats were right. And so I find, at least in my life, it is often the Catholics who deserve blame for their (agitating) presence. James Carroll (footnoted above) might agree. 
the rights (often repealed and reinstated almost on a rolling basis as control slipped in and out of the hands of Know-Nothing/Nativist legislatures in subsequent years ${ }^{5}$ ) of the now burgeoning Irish Catholic immigrant population, this alternate model of schooling created the flashpoint by which public schools were free to move from a Christian denominational spirit, to the new doctrine of late 19th century Americanism. Horace Mann and Noah Webster saw their common schools movement as inherently tied to "the principle of virtue and of liberty" in order to help students form an inviolable attachment not to religion but to country (Nord, 1995, p. 75). This, by 1890, meant that textbooks (recall the prevalence of the old New England Primer) at the high school level had eliminated explicit religious content almost universally. Even McGuffey Readers were being shunted to use in private schooling, now for the first time significantly outnumbered by public institutions. Patriotism had thus morphed into the new religion of schooling.

\section{The Courts}

This project of Americanization from the late 19th century onward led to the Progressive era (or rather a movement of progressivism) that put an emphasis on advancing American society, putting faith in expert (scientific) knowledge which could modernize (and industrialize) a burgeoning economy and nation. And so we have a movement to comprehensive high schools that educate for what Labaree (1997) might call social efficiency. All cogs in that Lancastrian machine. From here the assumption generally follows that as schooling in America became more sophisticated and widespread, we progressed, as it were, away from teaching religion in schools. Yet the notion that Americanization or progressivism did not eradicate the long-lasting intrusion of religion into schooling - indeed, that religion continued to play a role in education regardless of decades of attempts to secularize and "modernize" schools - is best evidenced by a series of court decision beginning in the 1940s regarding the relationship between religion and schooling in the U.S.

The foundation of which was established-pun intended-with Everson v. Board of Election (1947), in which, determining that the First Amend-

5 Indeed it was around this time, Carper (1998) reminds us, that Illinois and Wisconsin made it mandatory for children between 7 and 14 to attend sixteen weeks of public schooling a year. The Bennett and Edwards laws, respectively, were meant to undermine sectarian religious education as Catholic and Lutheran schools were seen as corrupting the ideal of evangelical Christianity espoused through public schooling ( $\mathrm{p}$. 18). Too, the Americanization project of public schooling was seen as vital to "alter" the inherently weak moral and spiritual constitutions of Irish and German immigrants, while grafting their loyalties to the federal project of patriotism. 
ment's establishment clause applies to state and, therefore, to local school districts, Justice Hugo Black asserted that:

The 'establishment of religion' clause of the First Amendment means at least this: Neither a state nor the Federal Government can set up a church. Neither can pass laws which aid one religion, aid all religions, or prefer one religion over another. Neither can force nor influence a person to go to or to remain away from church against his will or force him to profess a belief or disbelief in any religion. (Nord, 1995, p. 115)

In terms of legal ramifications, Black's interpretation held (and still holds) great weight and served as the foundation for various court decisions to follow. In 1948, debating the case of the People of Illinois $v$. Board of Education, the Supreme Court banned use of public school buildings for release-time religious instruction (Jurinski, 1998). In Engel $v$. Vitale (1962), one of the most significant and far-reaching cases heard by the Supreme Court, the Nine (reduced to seven in this case) examined the constitutionality of the New York State Regents tract, which read" , "Almighty God, we acknowledge our dependence upon Thee, and we beg Thy blessings upon us, our parents, our teachers, and our Country," and determined that school prayerwhether denominational or not-might be construed as a religious activity and thus declared it unconstitutional (Nord, 1995, p. 115).

A year later, in Abington School District $v$. Schempp, the Court reiterated its ruling. School-organized prayer including the recitation of the Lord's Prayer and required devotional Bible reading-even without comment or explication from teachers or students-was now illegal in the classroom.

In Stone $v$. Graham, the Supreme Court banned the display of the Ten Commandments in public schools, ruling that their purpose is religious and thus prohibited by the First Amendment's establishment clause as interpreted by Justice Black. In 1985, the Court invalidated an Alabama law that allowed for a one-minute period of silence at the beginning of each school day 'for meditation or voluntary prayer.' It was ruled that this mandated moment of silence amounted to "the State's endorsement of prayer activity." This, the court believed, "transgressed the proper wall of separation between church and state. Merely allowing students to be excused [was] held insufficient" (Jurinski, 1998, p. 49).

In 1992, in Lee $v$. Wiseman, the Court banned religious invocations at public school graduation ceremonies. And in 1995, the U.S. Department of Education, in a set of guidelines regarding religious activity in schools,

6 Recited daily, and statewide until challenged. 
states that student (individual or group) prayer and Bible reading ought be as long as it is not disruptive, as is the wearing of religious clothing and symbols, as well as limited proselytizing and distribution of religious literature. Banned, according to these guidelines, are teacher- and or school-endorsed prayer. Teachers, according to these guidelines, may teach about religion but cannot advocate on behalf of a particular religion. Nor may they encourage either religious or antireligious activity (Jurinski, 1998). The underlying assumption being, of course, that neutrality is possible. I remain dubious of such a claim, implicit or otherwise.

With an eye to the juridical-religious evolution of a public school system meant to be rendered irreligious by legal procedure, then, the interest in the remainder of this paper is less about the question of government entanglement with religious and Catholic schooling (long independent, and proudly so, of governmental intervention) and more about opportunism. What we find in the history of Dagger Hughes is a keen eye toward serving a need (parochial) but also a political end (growing ethnic religious sovereignty) that is being recapitulated in modern times. Now, with the Catholic schools ailing in enrollment and at the heart, in the coffers, a separatism borne of two centuries of tradition is being rent through a newfound alliance with the protagonists of neoliberal market instruments in the realm of schooling. I now turn to two interdisciplinary frameworks of thought that will help illustrate some of why this is happening; later I will provide two specific examples of how this looks in the modern American context through the Cristo Rey Network and the University Consortium for Catholic Education as manifest in the growing influence of the Alliance for Catholic Education at the University of Notre Dame.

\section{Framing}

"Critical social theory" for Leonardo (2009) is a multidisciplinary framework with the implicit goal of advancing the emancipatory function of knowledge" (as cited in Watkins, 2012, p. 3). Rooted firmly in a Marxist and liberatory understanding of both power and human possibility, it emerges from a Freirean tradition bent on the possibility for change fostered in something akin to the creation of the "critically transitive consciousness" which:

Is characterized by depth in the interpretation of problems; by the substitution of causal principles for magical explanations... by the attempt to avoid distortion when perceiving problems and to avoid preconceived notions when analyzing them; by refusing to transfer responsibility; by rejecting passive positions... by 
receptivity to the new for reasons beyond mere novelty and by the good sense not to reject the old just because it is old. (Freire, 1974, p. 14)

This is, in other words, the undoing of the commonsensical. In some sense this is the project of queer theory, of making strange that which purports (is purported) to be ordinary, but with explicitly politically emancipatory goals grafted on, rooted in. Absent the kind of "ludic postmodern" obsession with language over engagement in power politics that Mclaren (1999) laments, we might dwell in the discursive in interesting ways here. More pressing, however, and more salient for the ways in which Critical Social Theory gets leveraged in this article and in the larger project of questioning, queering, and pushing back against neoliberal education reform, is the notion that "politics" in the realm of schooled policy has been weaponized. Indeed education as a wedge issue has largely disappeared in the United States as neoliberal reformation of the public school system has become the lone bipartisan issue in the country. And these politics, "in other words" have come to "sanction and reproduce the disequilibrium of forces manifested in war" (Webb \& Gulson, 2011, p. 178). Rooted in a language of crisis (Kumashiro, 2012) taken from an ahistorical view of schooling on a whole, proponents of this latest round of reforms imposed from beyond the schools have created and leveraged their own manufactured "democracy-free zones-gaps in politics as usual when the need for consent and consensus do not seem to apply" (Klein, 2007, p. 175) as a way to produce multiple "technologies that marketize public schooling" (Webb \& Gulson, 2011, p. 174).

Most prominent for my purposes here are vouchers which "although their pro-voucher argument is framed in terms of parental choice" is rooted Robinson \& Lugg (2012) note, deeply in a "neoliberal attempt to 'marketize' the public school system to allow students to go to religious private schools using public funds" (p. 130). Which might not be the worst thing in the world if any long term data were present to support the gains made by students in these programs, but multiple studies show conflicted results, at best ${ }^{7}$. The point of course we find is that this isn't really about student learning gains, but rather has become about furthering political ends and

7 It's something of an adventure swimming through the evidence on this as so much of the data are produced and analyzed by charter/voucher advocacy organizations. Still Farrell \& Matthews (2006) provide a cogent and seemingly disinterested summary of studies (p. 523) in support of this claim of mixed-bag successes and failures. Another compendium of results can be found in Education Week (http://www.edweek.org/ew/ issues/vouchers/). Here one encounters a profusion of studies by the most prolific scholars in the American system, Jay Greene and Patrick Wolf who continue to find middling results. 
through ideological means which explicitly obfuscate "the history of Protestant conservatives' efforts to avoid desegregation" and their angst at "the loss of a federal tax exemption by conservative, segregated Protestant academies during the 1970s and 1980s" (p. 130). Which is to say, from a Critical Social perspective, the neoliberal movement in education isn't really about education at all, but about the orthodoxy of market ideology and the creation of a new market through the destruction of a system that long existed beyond the pale of profit margins. Were it any other way then the 2009 results from the Center for Research on Education Outcomes (CREDO) at Stanford University that showed no significant signs that charter schools operated any more efficiently in educating students than traditional public schools would have given someone pause in the broader network of education policy in the United States. The ability, however, of state legislatures to cut huge swathes from their budgets by spiking public schools in favor of charters or vouchers unleashed on a newly created private market proved too irresistible for Republican majorities; Democrats acquiesced as a new fiscal reality born of vast war expenditures, tax cuts and emptied government coffers emerged. Lost in the shuffle of course is any sense that "the end [goal] of public school[ing] is not profit maximization but public service" (Saltman, 2012, p. 64). And ultimately, children become commodified in the process, let us not forget.

We ought, however, get back to parochial schools and the religious import of such policies. Is it not right, in the newly competitive political-educational reality for religious schools to work to survive through the engagement with and pursuit of government funding? Ought one not argue that-given the belief that one is preparing kids for, as some colleagues have stated in their goals for a new model of Catholic education "college and heaven" $(<\mathrm{http}: / /$ ace.nd.edu/academies/>, nd.)—ends readily justify means? Perhaps. But perhaps, lost in the shuffle of this high-flown rhetoric, is any larger sense of civic service, of Catholic social teaching centered on being present to and with the poor, the disenfranchised. In other words, are Catholic schools by embracing the voucher movement and its secondary policy imports - the large scale disinvestment in the inner-city, in infrastructure spending, in health and food provisions for the impoverished - not suggesting that saving some few schools is a priority at the expense of the health and education of millions of other children? Are they not saying, tacitly, much as Barry Goldwater did that "the child" (of color, of reduced means, of different abilities) "has no right to an education; in most cases he will get along very well without it" (Reese, 2005, p. 242)?

We've gotten, in some sense, a bit far afield here, but it is vital that we make a case at this point for the convergence of a Critical Social Theory and 
an emergent Critical Religious (education) Theory. The latter of which would say that Catholic schooling and its policy pursuits in the United States ought most saliently be about producing the greatest possible "means of dignifying people so they become fully free to claim their moral and political agency" (Moyers, as cited in Giroux, 2009, p. 21). This is to suggest that the move of Catholic schooling in the United States to embrace neoliberal reform policies and to engage in a competitive model with public schooling is to actively do a disservice to a large swath of the population, and most particularly to the poor and the dispossessed, the least well served; those children that, in its health, the system once worked diligently to support. Given its shrinking size, the Catholic sector has come to wield undo and dangerous influence and has failed, in a religious sense, to engage in the fundamental social tenets upon which the Church claims to be founded. Cahill (2005) argues that this must mean that in the Church "we must seek out forms of behavior which challenge exclusionary and dominative social practices, and not leave the values of compassion and solidarity at an ineffective level of abstraction" (p. 129). That is, while it might be admirable to offer vouchers to students to give them access to some Catholic schools, as a suite of reforms rolled up in the neoliberal movement, this Trojan horse is actually causing a chasm of compassion to widen. Catholic schooling, in an attempt to save itself, is forgetting the people it could most broadly serve. At this point, we turn to specific nodes of power that illustrate this troubling trend in Catholic advocacy pointing out that leaders in the movement are perhaps best served to ask, thinking of Mark 8:36, "What good does it do a man to gain the whole world, yet forfeit his soul?" What good is saving Catholic schools at the expense of the greater soul of public education? I will suggest, at this point as well that the work of a Critical Religious (education) Theory requires engagement with "a fundamental insight of nonviolence theory...that unjust structures or practices can exist only so long as people go along with them" (Taylor, 2007, p. 64).

\section{Crises and Educating the Soul of a Nation}

The Catholic Church is, in many ways, in crisis mode. Indeed Hans Kung, long banned from officially teaching Catholic Theology by his contemporary and former friend the (also) former Joseph Ratzinger suggests in Der Speigel (2011) that though the then impending state visit of the reigning Pope to Germany might well showcase the façade of a powerful Church, we are better to note that though "it is certainly powerful," we might well ask, "is it healthy?" (p. 1). We might suggest the same imbalance of façade and crumbling infrastructure when considering the state of modern Catho- 
lic schooling in the United States. Long bolstered by the support of religious orders (e.g. the Sisters of Mercy, the Salesians, the Augustinians), Catholic schools find themselves affected by economics born of a crisis in vocations unprecedented in the history of the church. For the sake of scale consider the precipitous drop off of religious sisters in the United States from 1967 until 2010 , from roughly 275,000 to a wavering 55,000 . In that same period priests dropped by a somewhat more modest 19,000, though for a better sense of the effect of this smaller number, we should note that the ratio of Catholic laity to priests has risen by over 100 percent in the fifty years since the mid-sixties (Schuth, 2011).

The causes for such stark bleeds in vocation are myriad and not a little contested. They run the gamut from laments about a rapidly secularizing society, to questions about the efficacy of a model of celibate religious devotion and along the way toward the opening up of broader possibilities for women in the work world through this century prior (Carroll, 2001; Cummings, 2009; Madigan, 2011; Robertson, 2010; Wills, 2000). In Catholic schooling, however, the cause matters far less than the effects: a faculty in Catholic schools that is increasingly composed of lay members who require more maintenance than their ecclesial forebears, particularly the religious sisters of yore who worked as brides of Christ, the teaching its own reward as monetary and moral support was slow in coming, if it came at all from tight-fisted bishoprics (Cummings, 2009; Butler, 2012). The exploding cost of Catholic schooling can be neatly tied to the necessity to provide health care coverage, retirement benefits and at least some semblance of a living wage to retain quality faculty. Tuition, in the absence of federal and state funding, along with alumni donations maintains the schools and the former rises to cover instructional costs as the latter increasingly is steered towards the kinds of capital improvements (athletic fields, technological infrastructure) needed to compete for students whose parents no longer send them to parish and local Order schools slavishly for fear that they might lose their salvation in the halls of the public schools.

The trouble, of course, is that these schools view themselves as competing for a smaller pool of students who can afford to pay tuition, whose parents still value Catholic education (whether out of nostalgia based on their own experiences or out of a genuine desire for religious guidance; more insidiously, the option can be seen as a more racially pure option (Burke, 2011) in an educational market that focuses increasingly on the kinds of value-added assessments that aren't readily measurable in outcomes such as prayerfulness or liturgical devotion. Add to this spate of woes the outmigration of whites from cities and the subsequent unwillingness of alums to devote funds to schools no longer serving 'their' (in two senses) children, 
and you have Catholic schools essentially cannibalizing each other in an attempt to survive. Amidst this bleak picture, however, two approaches have emerged as potential saviors of Catholic education. They both embrace neoliberal reform tenets and in seeking to preserve Catholic education as a notion in the proud tradition of Dagger Hughes, require sacrifices of the poor at the altar of the market for the sake of some imagined greater good. Both rely on "the proliferation of alternative routes to teacher certification that challenge the 'monopoly' of the universities and promise improvement by infusing the market with alternatives" riding the wave of "support for such initiatives...despite compelling research revealing their ineffectiveness in improving school performance and teacher quality" (Kumashiro, 2012, p. 42). The Cristo Rey model of schooling relies on an instrumentalization of schooling that asks poor children to work for their spiritual and intellectual bread, as it were; the ACE model funnels underprepared teachers into Catholic schools, but also increasingly utilizes its lobbying arm to push for vouchers, charters and choice at the state level. I will examine the troubling policies of both programs below.

\section{Cristo Rey}

Nothing sums up the symbiosis of the new Catholic school model as envisioned by the proponents of neoliberal solutions from within quite like this headline from 1995 from the Chicago Sun-Times a daily paper in the Midwestern city: "Catholic Students Could Earn While They Learn" (Kearney, 2008). Masthead material certainly, but light on detail. What the article ended up elucidating was the beginning of a new model for inner-city schooling proposed and promulgated by the Jesuit order of priests meant to foster fiscal sustainability while providing strong academics to the immigrant populations once well-tended by Catholic institutions become unattainable bastions of privilege for the children of the city's elite. The model requires minimal tuition collection from parents, while relying on corporate partnerships ('Corporate Work Study'), which provide job-shares for students who work to 'earn' their remaining tuition one day a week, in rotation with four other peers. That is, for poor students in the inner-city of Chicago, the work of going to school was also about training, literally, in the offices of business entities downtown.

At this stage, some twelve years later, the Cristo Rey model has been replicated in twenty-three other schools nationwide spanning from Boston all the way across to San Francisco ("Cristoreynetwork.org," n.d.). These schools seek to provide a "lean college-prep school and curriculum" (Kearney, 2008, p. 108) for traditionally underserved populations, most notably Latino and 
African-American students and communities. Indeed the Cristo Rey Network, having grown beyond the bounds of that first school in Chicago has expanded its focus to become "a national voice and leader in the movement of education reform" seeking to redress "educational gaps" that impose "the economic equivalent of a permanent national recession" ("Cristoreynetwork. org," n.d.). And while the merits of better serving under-resourced communities are no doubt noble, we see here a betrayal of the underlying assumptions about student instrumentality that have long been seeded within the public debate about schooling and immigrants as well as other suspect communities in the United States. The Network's website suggests the transformative possibility of the "economic activity" the school brings to desolate communities, noting that "prior to a Cristo Rey school, neighborhoods [were] stricken by decades of serious poverty, crime, and violence on the streets" ("Cristoreynetwork.org," n.d.). Now we might argue that the poverty, crime and violence still persists in the inner-cities of the United States where Cristo Rey schools have sprung up (statistics to this end are easily enough accessible on the web, though it is true that violent crime on a whole has gone down nationwide) but that path is a bit of a red herring. What we ought focus on here, though, is the larger discourse of schooling as the solution for largescale public disinvestment in neighborhoods and civil/civic services as well as schooling's larger role of civilizing the savage. "The immigrant problem... is a big one and the biggest end of it falls upon the public schools" suggested William McKinley in 1898 and "for the peace and order of society, and the safety of our America institutions, one of two things must be done, and that speedily: either stop the tide of alien immigration, or provide schools where they can be educated to our standard of thinking" (Reese, 2005, pp. 55-56).

How better, then, to "educate" those few immigrants who escape the increasingly restrictive and vindictive policies of states in the US "to our standard of thinking" than to provide for their education through their own vocational placement within corporate entities who in return for investments deductible as charitable donations to the school, receive menial work from easily trainable children learning the docility of wage work as part of their official school curriculum? Or to put it another way, "to most educators...the idea of sending a fourteen-year-old freshman with limited English skills...into corporate America" before Cristo Rey schools "would have seemed completely off the wall" (Kearney, 2008, p. 85). Indeed. Giroux (2012) suggests that underlying this manner of reform, this open partnership between religious and corporate interests "are a number of forces eager to privatize schools, substitute vocational training for education, [and] govern schools that serve poor white and minority students through the axis of crime (p. 2). It's telling that the imagination of the Jesuit order in serving under-resourced students 
has been so limited by the educational discourse as to see corporate sponsorship and economic utility as primary concerns in the creation and promulgation of schools. Indeed this approach seems to run directly contrary to the guiding pedagogical document of the Jesuits, the Ignatian Pedagogical Paradigm (1993) which calls for educators in the Jesuit tradition to be "sensitive to their own experience, attitudes [and] opinions lest they impose their own agenda on their students (para. 26). One might ask, again examining the guiding pedagogical documents of the Order if this manner of education, which sacrifices one fifth of a poor-student's classroom time at the altar of corporate partnership, if this educational model is really about "radical transformation...seeking the greater good" (para. 19)? That is, what does it mean to serve small pockets of students in poor communities while advocating on the national level for broader reforms (vouchers, charters, etc.) that will alter the landscape of public (indeed all) education in the United States other than to feed the machine of oppressive neoliberal marketized education? We might ask, further, why it is acceptable in schools with poor children served by Jesuits for students to work-share in a lean college-prep environment while more affluent students in tony Jesuit schools are not fed to corporate job-shares once a week?

What has been created, in effect, is a two-tier system of Jesuit schools, one of which is able through donations and tuition collection to more fully, through a robust liberal-arts curriculum augmented by a bevy of extracurricular assets, "'discern'... [the] internal motivation' (para. 47) of a students' desires for and in the world while poorer students are exposed to, indeed coerced into the sort of non-reflective work of corporate drudgery (these are entry-level-mail-room jobs, recall) that prepares them for the docility of obedience rather than the thoughtfulness of leadership. This is, in effect, a larger-scale version of Anyon's (1981) school learning study: one group is being approached as future leaders, the other as future (and present) workers. And while we might congratulate the innovative approach of the Jesuits in creating schools that are perhaps better options than their public counterparts in some neighborhoods, we ought remind them that Catholic schools were never meant to compete with public schools, they were to be apart and offer different visions; we might cite the concept of Magis which the Order sees as a call to ever do 'more' in its work: more can be done for and with the poor just as it is done with the affluent, the privileged. Now let us turn to the notion of advocacy for broader policy which has, of late, become a large part of the Catholic marriage with the reform movement. 


\section{The Alliance for Catholic Education}

Kevin Kumashiro (2012) addresses a growing concern:

Another example of market-based solutions is the proliferation of alternative routes to teacher certification that challenge the 'monopoly' of the universities and promise improvement by infusing the market with alternatives. Support for such initiatives continues to grow, despite compelling research revealing their ineffectiveness in improving school performance and teacher quality. (p. 42)

In the interest of full disclosure I should note that I am both a product of such an alternative route and a current faculty member within the same organization. We are purveyors of a two-year MEd that rush certifies teachers for Catholic schools. That said, though I think programs like our own, the Alliance for Catholic Education, do interesting things in terms of recruiting high achieving undergraduate students who might not otherwise enter teaching, and in this case, the teaching profession in Catholic schools, we are by and large a stopgap measure. The two-year rotation of the program (much in the vein of other programs like Teach for America to name the most prominent in the US) ensures a constant churn of teachers in the poorest schools with half of our candidates thrust into their first year after six short weeks of accelerated training. They are content masters (or so their undergraduate degrees tell us) but they may not know anything about actually teaching no matter how much we work to ameliorate this troubling reality in their brief coursework with us.

This piece is no encomium for or ode to traditional teacher education, though. Rather, what I'd note is that Catholic schools and particularly Catholic universities, in answer to the exodus of vowed religious have chosen to turn to the neoliberal model of temporary teachers to solve the problem of health care (young people straight out of college inevitably cost less than those with families to cover and as of now can be kept on their parents' health plan until the age of 26, further lowering sunk cost), benefits and salary. All of this, of course, at the potential expense of the learning of students and the environment/community of the schools. Performance (learning), in other words, is secondary to the survival of the school and this explains both the explosion of the University Consortium for Catholic Education, which I will discuss further now and the expansion of offices like my own which maintain in-house staff to advocate for voucher and choice programs at the state level ostensibly to provide education to students, but moreso to 'save' Catholic schools from sinking under the strain of reduced 
enrollments. What is intended by this latter move, I will argue is something akin to Roger Dale's caution that "in education, the new reliance on competition and choice is not all pervasive; instead, what is intended is a dual system, polarized between...market schools and minimum schools" (as cited in Apple, 1996). We have seen above one version of the minimum school imagined by Catholic reformers; here we will examine other instruments creating the same structure whereby Catholic schools, (mostly in poor urban areas) long proudly separate from and importantly, different than, public schools, turn their sights toward competition with their public counterparts at the cost of both Catholic identity and the very public good that Bryk, Lee and Holland (1993) envisioned this sector as once serving. The University Consortium for Catholic Education grew out of:

A movement beg[u]n in the mid to late 1990 s by Catholic universities to develop teacher preparation programs that would support Catholic education by recruiting and training faith-filled, energetic men and women to serve as teachers in the Catholic schools across the nation. ("UCCE history", n.d.)

Currently the Consortium comprises fifteen programs at fourteen universities that offer alternative and accelerated routes into the classroom across the United States placing over "400 teachers in Catholic/parochial schools in approximately 25 states each year." One might argue that these are jobs that otherwise wouldn't be filled with teachers with content mastery, but we also might be concerned with the filling of local jobs by teachers from across the country who swoop into the community and more often than not leave the school and leave teaching after their two years of 'service' are up. This is a way of maintaining schools without addressing larger structural issues like poverty in communities that make tuition beyond the reach of most inner-city students. Rather, what the Consortium creates, like its public sector counterparts in TFA is a resume builder for affluent undergraduates, privileged enough to take two years to dabble in the profession, debt by and large not a concern; the corollary effect is the rapid deprofessionalization of teaching in the social imagination as well (Ravitch, 2010; Saltman, 2012). Perhaps as troubling are the universities like Boston College that maintain a Consortium program (UCTC) as well as a traditional undergraduate and graduate program of teacher certification. They are essentially presenting competing models and, in Boston, holding jobs for UCTC members at the expense of their traditional education graduates who might otherwise commit themselves to a long-term career serving in a school. This alternative route issue is certainly troubling, but more striking is the move toward political advocacy embodied in the creation of the Program for K-12 Edu- 
cational Access at the University of Notre Dame under the auspices of the ACE program (apologies for the alphabet soup of acronyms here, but these are capital letters worth attending to for the insidious implications hidden behind innocuous names).

Run by two legal scholars (with no history of theoretical or pedagogical research in education itself), the PEA in its own words is "informed by Catholic social teaching" and is "animated by an appreciation of parents/guardians as the primary educators of their children" while it "seeks to cultivate data-driven, parent-centered education reform" (“About the PEA," n.d.) which is to say that the organization pushes for political expediency in supporting charter and voucher legislation throughout the United States. Missing in this rhetoric of Catholic social teaching, of course, is a broader sense of the effects that Choice legislation has on public schooling and the vast numbers of children who are not currently and can not ever be educated in Catholic schools because of basic problems of infrastructure. There just aren't enough buildings nor, as noted above, enough teachers to serve in these hypothetical Catholic bastions of learning. The PEA touts its role in facilitating a dialogue about schooling in the United States through recent conversations held at the University featuring a who's who of Choice advocacy, including: Michelle Rhee, Howard Fuller, John Dilulio, Terry Moe, Jeb Bush, Chris Christie and Bob McDonnell all of whom are noted advocates for voucher programs and in the case of Rhee, notorious for inconsistencies in data (see, for example, Ravitch, 2011) while also championing the active destruction of teachers unions. What the PEA does, in effect, is provide a forum for voucher advocacy awash in the language and trappings of Catholicity, couched in individual choice and parental duty, meant to save Catholic schools. The trouble, of course, is that no account is taken of the effects on public schooling that this advocacy and its sudden outsize influence can carry. Given the data noted above that suggests that charter and choice advocacy isn't really about improving education so much as marketizing it, I find this advocacy work the most troubling though perhaps not surprising when run by neophytes largely unfamiliar with the rigors and nuances of, as well as historical debates within, education research. The research, the data don't matter, in other words, when the rhetoric is about saving the souls of Catholic schools to say nothing of all of the Catholic kids in public schools whose richness of experience is undermined by the concurrent push to defund public schooling and force more testing upon already beleaguered teachers and students.

The point in the above is this: considering the long history of separate spheres in the US system of schooling, when Catholic schools prided themselves on their self-sufficiency and quality in providing a different kind of 
education, competition with public schools was never the point. The move now to advocate actively for vouchers and increased competition for monies is going to have two direct effects: 1) the homogenization of Catholic schools which will, inevitably as money always has strings, come to be influenced by and accountable to the same testing regimen that the public sector has faced for years and 2) the realization that Catholic schools, by traditional measures, are like all schools: good at some things and bad at others. Hallinan \& Kubitschek (2012) and Reardon, Cheadle \& Robison (2009) are already producing data to this effect and should Catholic schools choose to ignore the long-term effects of these self-inflicted wounds, their scramble to save themselves through market instruments may just spell a quicker doom.

\section{Closing}

The move to align Catholic schooling, Catholic teacher preparation and Catholic educational lobbying with marketized neo-liberal reforms in the United States is perhaps not surprising given the abject fear that comes about from extreme contraction. That Catholic schools are struggling is not surprising. Indeed we know the causes. That they can be 'saved' is perhaps up for debate, but that there is a worthy cause perhaps for advocacy is worth considering. Lost, however, amidst this fear, is any sense of nuance nor any turn to larger structural inequities that might be adversely affecting schooling on a whole and Catholic schools specifically. That is, what if we were to consider the broad disinvestment in the public social contract, in the name of Catholic Social Teaching, say, rather than focusing in on how to better compete for a shrinking pool of money for education? What good might be done to advocate for better services for all children rather than leaner models perpetrated on a notion that winners and losers are necessary in a market system?

But of course, as Kumashiro (2012) reminds us, "fear makes us less likely to question what has become taken for granted as the solution to our problems, and less likely to seek out a vision of the bigger picture" (p. 29). This is forest and trees stuff, in other words. And lost in the pursuit of saving those few Catholic schools that might temporarily benefit from the knee-jerk move to advocate for and take advantage of market solutions through competition, is the larger forest of problems that emerges from such a utilitarian approach to politics and education policy. In other words, the kids end up sacrificed at the altar of ideology. It would be easy to turn here to other issues within the Church where the preservation of the Institution was given precedence over the protection of the flock at large, but that's another work for another time. Rather here, we must take pause at the impending policy 
ramifications of Catholic advocacy for government intrusion even as certain elements of the Church battle perceived attacks on religious freedom, and note that though advocates of market reforms like the Cristo Rey school model and the UCCE teacher preparation programs are certainly convicted by the benefits and righteousness of their current cause, for lack of a larger historical vision of schooling in the United States, they (we) may well be convicted in the light of historical memory as having made short-sighted and selfish decisions in the name of some few, at the cost of a great many children.

\section{References}

Alliance for Catholic Education. Notre dame ACE academies. Retrieved May 1, 2012, from http://ace.nd.edu/academies

Alliance for Catholic Education. Program for educational access. Retrieved May 18, 2012, from http://ace.nd.edu/pea

Anyon, J. (1981). Social class and school knowledge. Curriculum Inquiry, 11(1), 3-39. Apple, M.W. (1996). Cultural politics and education. New York: Teachers College Press.

Bryk, A., Lee, V., \& Holland, P. (1993). Catholic schools and the common good. Cambridge: Harvard University Press.

Burke, K. J. (2011). Masculinity and other hopeless causes at an all-boys catholic school. New York: Peter Lang.

Burke, K. J., \& Segall, A. (2011). Christianity and its legacy in education. Journal of Curriculum Studies, 43(5), 631-658.

Butler, A. M. (2012). Across god's frontiers: Catholic sisters in the american west: 1850-1920. Chapel Hill: University of North Carolina Press.

Cahill, L. S. (1996). Sex, gender \& christian ethics. Cambridge: Cambridge University Press.

Carper, J. C. (1998). History, religion, and schooling: A context for conversation. In J. T. Sears \& J. C. Carper (Eds.), Curriculum, religion, and public education: Conversations for an enlarging public square. New York: Teachers College Press.

Carroll, J. (2001). Constantine's sword: The church and the Jews. New York: Mariner Books.

Center for Research on Education Outcomes. (2009). Multiple choice: Charter school performance in 16 states. Stanford, CA: Author.

Cristo Rey Network. Impact. Retrieved May 12, 2012 from http://www.cristoreynetwork.org/page.cfm?p=354

Farrell, W. C., \& Mathews, J. (2006). The milwaukee school voucher initiative: Impact on black students. The Journal of Negro Education, 75(3), 519-531. 
Giroux, H. (2012). Education and the crisis of public values: Challenging the assault on teacher, students, and public education. New York: Peter Lang.

Giroux, H. A. (2009). Youth in a suspect society. New York: Palgrave Macmillan.

Hallinan, M. T., \& Kubitschek, W. (2012). A comparison of academic achievement and adherence to the common school ideal in public and catholic schools. Sociology of Education, 85(1), 1-22.

The Daily Show with Jon Stewart. Interview with Cathleen Caveny. Retrieved May 12, 2012, from http://www.thedailyshow.com/watch/thu-march-1-2012/exclusive-cathleen-kaveny-extended-interview-pt-1

Jurinski, J. (2004). Religion on trial: A handbook with cases, laws, and documents. Santa Barbara: ABC-CLIO.

Kearney, G. R. (2008). More than a dream: How one school's vision is changing the world. Chicago Loyola.

Klein, N. (2007). The shock doctrine: The rise of disaster capitalism. New York: Picador.

Kolvenbach, P. H. (1986). No small task. Toronto: Regis College Press.

Kumashiro, K. K. (2012). Bad teacher! How blaming teachers distorts the bigger picture. New York: Teachers College Press.

Labaree, D. F. (1997). Public Goods, Private Goods: The American Struggle Over Educational Goals. American Educational Research Journal, 34(1), 39-81.

Madigan, P. (2011). Women and fundamentalism in islam and catholicism: Negotiating modernity in a globalized world. Bern: Peter Lang.

McLaren, P. (1999). Schooling as a ritual performance: Toward a political economy of educational symbols and gestures. New York: Rowman \& Littlefield.

National Catholic Education Association. Annual data report: Catholic schools. Retrieved May 1, 2012, from http://www.ncea.org/news/annualdatareport.asp

Nord, W. A. (1995). Religion and American education: Rethinking a national dilemma. Chapel Hill: University of North Carolina Press.

Ravitch, D. (2010). The Death and Life of the great american school system: How testing and choice are undermining education. New York: Basic Books.

Ravitch, D. (2011). Shame on michelle rhee. The Daily Beast. Retrieved from http:// www.thedailybeast.com/articles/2011/03/29/michelle-rhees-cheating-scandaldiane-ravitch-blasts-education-reform-star.html

Reardon, S. F., Cheadle, J. E., \& Robinson, J. P. (2009). The effect of catholic schooling on math and reading development in kindergarten through fifth grade. Journal of Research on Educational Effectiveness, 2(1), 45-87.

Reese, W. J. (2005). America's public schools: From the common school to 'no child left behind'. Baltimore: The Johns Hopkins University Press.

Robertson, G. (2010). The case of the pope: Vatican accountability for human rights abuse. New York: Penguin. 
Robinson, M. N., \& Lugg, C. A. (2012). The role of the religious right in restructuring education. In W. H. Watkins (Ed.), The assault on public education: Confronting the politics of corporate school reform. New York: Teachers College Press.

Saltman, K. (2012). The rise of venture philanthropy and the ongoing neoliberal assault on public education: The eli and edythe broad foundation. In W. H. Watkins (Ed.), The assault on public education: Confronting the politics of corporate school reform. New York: Teachers College Press.

Society of Jesus. (1993). Ignatian pedagogical paradigm. Rome, Italy: Author.

Taylor, R. K. (2007). Resistance. In B. Birnbaum (Ed.), Take heart: Catholic writers on hope in our time. New York: Crossroad Publishing.

United States Census Bureau. The 2012 statistical abstract: Education. Retrieved May, 1, 2012, from http://www.census.gov/compendia/statab/cats/education.html

University Consortium for Catholic Education. History. Retrieved May 18, 2012 from http://ucceconnect.com

Watkins, W. H. (2012). The assault on public education: Confronting the politics of corporate school reform. New York: Teachers College Press.

Webb, S. H. (2000). Taking religion to school: Christian theology and secular education. Grand Rapids: Brazos Press.

Webb, P. T., \& Gulson, K. N. (2011). Education policy as proto-fascism: The aesthetics of racial neo-liberalism. Journal of Pedagogy, 2(2), 173-194.

Wills, G. (2000). Papal sin: Structures of deceit. New York: Image Books.

\section{Author:}

Kevin Burke, PhD.

University of Notre Dame

Institute for Educational Initiatives

207P Carole Sandner Hall

Notre Dame

IN 46616

USA

email: kburke1@nd.edu 